\title{
THE EFFECTIVENESS OF SEMANTIC MAPPING AS PREWRITING ACTIVITY IN ARGUMENTATIVE WRITING
}

\author{
Ance Jusmaya. Universitas Putera Batam \\ jusmayaance@gmail.com \\ Afriana. Universitas Putera Batam \\ afrianaupb@gmail.com
}

\begin{abstract}
Abstrak
Saat ini, kemampuan menulis secara ilmiah menjadi keterampilan yang penting dikuasai oleh mahasiswa. Mahasiswa perlu memiliki keterampilan menulis yang baik dengan menggunakan penalaran dan logika yang berfokus pada apa yang harus dipercayai atau dilakukan berdasarkan mekanisme, seperti melakukan analisis konseptual dan argumen untuk pemecahan masalah dan pengambilan keputusan. Konsep semantic mapping adalah strategi yang efektif untuk meningkatkan kemampuan menulis mahasiswa. Penelitian ini mengeksplorasi efektivitas konsep semantic mapping pada pengembangan kemampuan menulis mahasiswa dalam menulis agumentatif essay. Penelitian ini diklasifikasikan ke dalam desain kuasi eksperimen. Dalam penelitian ini populasinya adalah mahasiswa Universitas Universal Batam yang terdaftar pada tahun akademik 2018-2019. Instrumen penelitian ini adalah tes menulis. Data dianalisis dengan beberapa analisis yaitu pengujian normalitas, pengujian homogenitas, dan pengujian hipotesis. Dalam menguji hipotesis penelitian ini, peneliti menggunakan uji-t untuk sampel terkait dan uji-Wilcoxon.Berdasarkan analisis ditemukan bahwa skor rata-rata mahasiswa pada pre tes adalah 7,89 dan skor rata-rata mahasiswa pada post tes adalah 12 . Nilai-t hitung adalah $t=3,83$ dan standar signifikan 0,05. Sementara t tabel hanya 2.306. Karena $t$ hitung lebih besar dari t tabel (tobserved $>t$ tabel), sehingga hipotesis nol (Ho) ditolak dan hipotesis alternatif (Hi) diterima. Jadi, berdasarkan hasil ini, disimpulkan bahwa ada perbedaan statistik antara pre-test di tingkat 0,05. Ini berarti bahwa pembelajaran menulis argumentatif berdasarkan teori semantic mapping memberikan pengaruh yang signifikan terhadap kemampuan menulis argumentatif mahasiswa.
\end{abstract}

Kata Kunci: Semantic Mapping, Prewriting Activity, Argumentative Writing, Writing Ability

\section{INTRODUCTION}

As international language, English is used to conduct communication, in almost the entire world in many countries. It is the major language which is used by people in some sectors in other words and it is defined English is being worlds' current lingua franca. As a result, english is used for obtaining successful jobs, promotions, academic function, and business interaction and many people tend to master English to compete in globalization.

As one the four languages skill, writing has occupied a place in English sylabuse. It is a skill that is acquired through study. Writing is one of English skills that should be taught integratedly. It is taught as the first foreign language as one of the important subjects in Indonesia. In this Era students need to master all English Skill such as listening, speaking, reading and writing. It is becouse of by the end of the learning process ,the students are expected to be able to communicate in English not only spoken but also in written form. Actually in writing, there are many genres that must be mastered by the students. It can be argumentative writing, descriptive, narrative, etc. To achieve the aim of 
learning, the students are required to write efficiently and effectively composition of these those genres. Among those genres, argumentative writing was found as more important than the other types of text because argumentative writing itself is the ability to write logical arguments based on substantive claims, reasoning and relevant evidence based on acdemic writing standards. In other words, it needs arguments that deal with probabilities (Hasani, 2016).

Based on the writer's observation in some universities in Batam it is found that most students think that English is the most difficult skill to learn. For example they had difficulty in determining the content of their writings and organizing them into comprehensible ideas. As we know that writing has a great correlation with a number of grammatical rules however for them creating correct grammatical sentences was not easy. It could be seen from their writing result that most of them still directly translated Indonesian sentences into English, so that the structures of the sentences were incorrect. It will give effect to the result of their writing which is meaningless. Besides, In terms of writing mechanics, the students sometimes made spelling mistakes. Another writing mechanic problem had something to do with the use of capitalization, commas, and full stops, particularly in writing descriptive text.

Based on the writer's interview with some lecturers of Universities in Batam, there were at least two problems which caused the students' difficulties in writing. The problems were lack of background knowledge about rules of writing and lack of activitiies provided by the teacher's in teaching writing. Actually, writing tends to not tolerate mistakes in its final product.
There are a number of conventions that cannot be separated from writing such as the issues of spelling, handwriting, grammar, capitalization, and punctuation. These complex rules of writing are the influential reasons why English language learners find it difficult to write well in English Therefore it is hard for the student when they have to arrange their ideas in sequential and logical orders to make the whole information easily understood by readers. In this case they have to get the basic knowledge about schematic structure and linguistic features of writing because a good writing is done from a set of rules and principles.

Besides, the problems also caused by the lecturers which lack of providing activities in teaching writing. For example the choices of teaching activities are monotonous. The teacher rarely used interesting instructional media, particularly to teach writing. She still depended a lot on the printed materials and textbooks in teaching the students. Then, in teaching and learning process the teacher just gave a topic to the students and asked them to write a composition without considering the way the students to learn. Then, Some students found difficulties in making the writing organize well. In writing, the writers must make ideas clear not only for themselves, but also for their readers. Becouse of that as a writer, they should follow the steps of writing, that is pre writing. However most students have heard of the term "prewriting," but they either do their writing without much premeditation or are unaware of their prewriting processes and the benefits of these practices. For example, if a student has to write a paper about a controversial issues, it may be good for them to create something like a concept map to break down exactly what that is 
comprised of. As a result, their writing will be acceptable. But in fact, it is hard for them to apply prewriting activties that actually can help them to organize their ideas clearly during the process of writing.

In prewriting activities refer to any activity that helps a writer think about a topic, determine apurpose, analyze anaudience, and prepare to write. Thus Prewriting involves anything that the writer do to help them decide what their central idea is or what details, examples, reasons, or content they will include in writing. Pre writing basically is simply tools for generating and organizing ideas. So that students will write a good writing later on. One of strategies that can be used in prewriting activities is Semantic Mapping.

Based on the writer's experience in teaching argumentative writing, it found that the students had low writing performance. For example,they tried to communicate their critical thinking skills through some ways such as writing in their first language or presenting their ideas in the teacher-student conference in prewriting stage by using code-switch. They stiil found problem in understand arguments, judge information, and make inferences in writing. In fact, these skills are very important for success not only in university, but also in the workplace. Besides, in some situation the students can take care of the grammar, vocabulary, the format, but if there is no depth of thought they will not be able to analyze, interpret and explain all these ideas the depth of development in good writing. In argumentative writing is students need arguments that deal with probabilities. Therefore, the writer who want to write argumentative writing must be qualified to convince their readers. In argumetative writing the students should be able to conduct their ideas systmeatically. One of the best ways to organize the ideas critically is using semantic mapping.

\subsection{Problem Formulation}

The writer formulates main problem to be answered as staed in following research question:

1. Is there any significant difference between pretest-post test students writing ability in terms of usage semantic mapping in argumentative writing?

2. How does the semantic mapping give influence to students'writing ability?

\section{Review on Related Studies}

According to (Nurcihan, 2013) semantic Mapping is a graphic arrangement of words that shows how new words and ideas can be related to each other within a text. So, it can be claimed that Semantic Mapping is an effective diagnostic tool that used by teachers to help their students who have problems with writing. Thus, it can be word maps that use drawing or diagram of words in line, boxes, arrows, circles in order to show ideas that related to the topics.

Semantic mapping is a strategies of prewriting that represent graphical concepts. It is an effective diagnostic tool. It is also a visual and structured strategy for vocabulary development and knowledge expansion displayed in categories of words in relation to other words. It is opposed to an unstructured strategy, which shows the hierarchical relationship of ideas such as brainstorming, in which students are free to generate ideas on paper randomly. Brainstorming is an application of schema theory that explains how people 
incorporate new information with their existing knowledge.

Semantic mapping is a useful strategy in writing that can be introduced to students at any level of proficiency (Scott \& Worden, 2012). Semantic involves drawing a diagram of the relationships between words according to their use in a particular text. It has the effect of bringing relationships in a text to consciousness for the purpose of deepening the understanding of a text and creating associative networks for words. Such a diagram "visually shows how ideas fit together. (Zahedi \& Abdi, 2012)state that semantic mapping incorporates a variety of memory strategies like grouping, using imagery, associating and elaborating and it is important for improving both memory and comprehension of new vocabulary items. Thus, in a guided of semantic mapping, students can work with the teacher to develop a semantic map around a topic, the teacher deliberately introduces several target vocabulary items and puts them on the map as well as elaborating on them with the learners who then use the semantic map to do a piece of writing.

According to (Nurcihan, 2013) semantic mapping is a visual strategy which shows the major ideas of a certain topic and how they are related. In other words, it is graphic displays of words meanings that offer students a visual representation of how words and concepts are related through a network of organized knowledge. It looks a graphic arrangement showing the major ideas and relationships in text or among word meanings designed to graphic and visual relationship of concepts or ideas.

Katagall, Dadde, Goudar, \& Rao, (2015) state that the semantic mapping has essentially two aspects. They are visual and conceptual. A visual semantic map is made up of forms, such as circles, triangles, etc. A conceptual semantic mapping contains verbal information inside and between the forms, which represents relationship between words or ideas. Thus semantic mapping is one way of representing and communicating one's understanding of concepts. Semantic mapping is designed to have students prepare and share new knowledge of the words, phrases, sentences, paragraphs, text, or discourse they have learned with a partner, other groups, or individuals during centers'.It means that semantic mapping strategies presented here can be used with individuals, small groups, or even the entire class. Semantic mapping can also be introduced by inviting students to write important information on separate index cards, slips of paper, or sticky notes. Semantic mapping as visual categorization of information serve a number of purposes. First, if one person show to another how relationship between may be represented using semantic mapping, she or he reveal to categorize, relate, and organize ideas. It mean that semantic mapping help students develop prior knowledge by seeing the relationships in given topic. And also helps students to visually organize information and can be an alternative to note taking and outlining.

Semantic mapping is a kind of map or graphic representation of categories of information and has relationship to each other; that can help the students to remember the words and their connection easily. According to (Leydesdorff \& Welbers, 2011) semantic mapping is a visual representation of knowledge, a picture of conceptual relationship. It means that semantic mapping can be as a visual representation of knowledge. Semantic 
mapping is believed as a useful technique to facilitate the students in comprehending texts properly.

Semantic mapping activity used as the pre-writing phase of a lesson can activate learners' schemata by introducing them to the relevant key words. As a pre-writing activity, educators can use core questions to enhance the comprehension of key words. More important, the connection between the main ideas and supporting details is based on a system of logic. This system describes about logical thinking. It contains a notion representing propositions and rules of inference on how propositions are going together to form valid arguments.

From thedescription ebove it can be conclude that semantic mapping in teaching writing can be done done before the students startwriting. The Semantic mapping technique can help students in finding ideas before they begin to write a composition or an essay more easily. In short, the Semantic Mapping technique is a strategy for visually expanding vocabulary and extending knowledge by displaying categories of words related to one another in a graphic fom. It is also an adaptation of the concept or definition of mapping and builds on students' prior knowledge or schema.

In writing, the writer must have indirect communication ability, language structure, writing techniques, and the ability to extract ideas form text(Hasani, 2016) .As a result, the mastered of writing should undersatnd the complexity of writing activity it self that requires systematic and well-ordered thinking.Therefore, Writing to be the most complex ability in English skill.

Basically, writing skills are not categorized as cultural knowledge, nonetheless they can be achieved by learning and training processes (Dwyer, Hogan,\& Stewart, 2015). One important type of writing to be learned in school and in the university is argumentative writing. It has an effect on the success of learning. At university, students usually write argumentative writing when they create a paper for daily routine tasks or thesis. Mostly, the students use argumentative writings in writing a paper deals with new and original ideas, and it must be written with strong and convincing argumentation. In this case they need some strategy to organize their ideas in the form of argument mapping.

The main obstacle in argumentative writing is the indicator to measure the success. The success of argumentative writing is when reader can be persuaded, brought, and conveyed to the paradigm that is stated and believed by the writer . In other word, good argumentative writing should contain several aspects which are data , claim ,warrant ,backing ,modal qualifiers (Liu \& Stapleton, 2014). Therefore, in argumentative writing the supporting paragraph should include facts, statistics, and concepts that support the writer viewpoint on a topic. In this writing the writer should investigate a topic; collect, generate, and evaluate evidence; and establish a position on the topic in a concise manner

\section{Research Method}

This research is classified into a quasiexperimental design. The researcher used this design because it is impossible to carry out experiment in the real setting like randomly allocate participants into groups. Quasi experimental design exists for situation in which 
complete experimental control is difficult or impossible.

In this research, the researcher will determine and observe the effectiveness of concept semantic mapping on development students's writing ability in argumentaive writing . The design of the research is as follow:

\begin{tabular}{|llllll|}
\hline D1O2 & O3 & $\mathrm{X}$ & O4 & O5 & O6 \\
\hline
\end{tabular}

Notes:

O1,O2,O3 : Repeatedly pre-test

X $\quad$ : Treatment (Teaching argumentative writing prepared based on Semantic mapping )

O4,O5,O 6 : Repeatedly post-test.

\subsection{Data Collection Techniques}

The research conducted the reserach at Universal University. Population is the entire group of interest to the researcher to which she or he would ideally like to generalize study result. In this research the population is the the third year students of Universal University Batam registered in 2018-2019 academic year. The instruments of this research is writing test. To know students' ability in argumentative writing, this research uses writing test. There are three pre tests and post tests. The pre-test are used to see students' writing skill before having treatment and posttest are used to see the differences on students writing skill after giving treatments. The writer asks the students to write argumentative writing based on the topic.

In this research, validity testing involves content validity. Content validity is a particular importance for achievement test. Since the purpose of this research is to find out the effectiveness of concept semantic mapping on argumentative writing toward students writing ability, the most suitable validity is content validity.

\subsection{Analysis Method}

The data were obtained through students argumentative writing achievement on pre test and post tests. After collecting the data, the data was analyzed by some analysis. They are normality testing, homogeneity testing , and hypothesis testing. In testing the hypotheses of this research, the researcher used T-test for related samples and wilcocon t-test. The statistical analysis used in this research will compare the highest pre-test mean and the highest post-test mean

Then, hypothesis testing computed by using t-test for two related samples if the data groups of the research are distributed normally and has homogenous variance. Then, from the calculation of wilcoxon t-test, $\mathrm{z}$ score is compared with critical value by using level of significant 0.05 . If the $\mathrm{Z}$ score is smaller than critical value, then the null hypothesis (H0) is rejected. This means that the research hypothesis (H1) is statistically accepted. In other words, if the $\mathrm{Z}$ score is bigger than critical value, then the null hypothesis (Ho) is accepted and the research hypothesis (H1) is statistically rejected (Gravetter and Wallnau, 2004)

Then, hypothesis testing computed by using t-test for two related samples if the data groups of the research are distributed normally and has homogenous variance. From the calculation of Wilcoxon T-test, $\mathrm{Z}$ score is compared with critical value by using level of significant 0.05 . If the $\mathrm{Z}$ score is smaller than critical value, then the null hypothesis (H0) is rejected. This means that the research hypothesis (H1) is statistically accepted. In other words, if 
the $\mathrm{Z}$ score is bigger than critical value, then the null hypothesis (Ho) is accepted and the research hypothesis (H1) is statistically rejected ( Gravetter and Wallnau, 2004:646) In this research, the writer determine and observe the effectiveness of concept semantic mapping on development students's writing ability in argumentaive writing

\section{DISCUSSION}

The data of this research were from writing test and the result of repeatedly pre-test and post test. The pre test and post test were conducted three times. The purpose of those tests were to see student's writing ability. The sample of this reserach was second year students of Universal University which consist of 42 students. These students were taught writing by using semantic maping in prewriting activities.Based on the reserach finding, it was proved that teaching argumentative writing prepared based on semantic mapping theory gave significant effect toward student's argumentative writing ability. More information is shown in the following table.

Table 1. The summary of Students' Argumentative writing ability on pre-test and post-test

\begin{tabular}{|l|l|l|l|l|l|l|}
\hline Statistic & $\begin{array}{c}\text { Pre- } \\
\text { test } \\
\mathbf{1}\end{array}$ & $\begin{array}{c}\text { Pre- } \\
\text { test } \\
\mathbf{2}\end{array}$ & $\begin{array}{c}\text { Pre- } \\
\text { test } \\
\mathbf{3}\end{array}$ & $\begin{array}{c}\text { Post- } \\
\text { test } \\
\mathbf{1}\end{array}$ & $\begin{array}{c}\text { Post- } \\
\text { test } \\
\mathbf{2}\end{array}$ & $\begin{array}{c}\text { Post- } \\
\text { test } \\
\mathbf{3}\end{array}$ \\
\hline Max & 12 & 12 & 12 & 14 & 14 & 14 \\
\hline Min & 5 & 5 & 5 & 5 & 8 & 10 \\
\hline Mean & 7.22 & 7.89 & 7.56 & 11 & 11.89 & 12 \\
\hline SD & 2.54 & 3.14 & 2.56 & 3.16 & 2.47 & 1.73 \\
\hline
\end{tabular}

As seen from the table above, the highest pre-test mean was 7.89 that was found at the second pre-test and the highest posttst was 12 that was found at the third post test. The highest score on pre-test was 12 and the highest score on post test was 14. The lowest score on pre-test and post-test was the same that was 5 .
In order to find out the effect of teaching argumentative writing prepared based on semantic mapping theory toward students argumenative writing ability, $t$-test for related samples and Wilcoxon $t$-test were used. These tests were used to test the hypotheses of the research. To test the hypotheses, the effect of teaching argumnative writingprepared based on semantic mapping theory were tested. The explanation below shows the effectiveness of teaching writing prepared based on semantic mapping theory.

There is a significant diffrence between pre-test and post-test score of the students who taught prepared based on semantic mapping theory toward their argumentative writing ability. The criterion to accept or reject this hypothesis was formulated as follow:

H0 : Students Writing ability on post test after having teaching argumentative writing prepared based on semantic maping theory is as the same as on pretest

H1 : Students Writing ability on post test after having teaching argumentative Writing prepared based on semantic mapping theory is better than pretest

The hypothesis was tested by using t-test elated samples samples that compare the highest pretest mean with the highest post test mean. From the data analysis, it was found that there is a significant diffrence between pre-test and post test score of the students who taugh based on semantic mapping theory toward their argumentaive writing ability. For futher description, it can be seen in the table below: 
Table 2. Result of $t$-test analysis of linguistic group

\begin{tabular}{|l|l|l|l|l|l|l|}
\hline $\begin{array}{l}\text { Teaching } \\
\text { writing } \\
\text { by using } \\
\text { semantic } \\
\text { mapping }\end{array}$ & Statistics & Mean & L Observed & L table & Note \\
\cline { 2 - 5 } & & $\begin{array}{l}\text { Pre- } \\
\text { test }\end{array}$ & 7.89 & 3.83 & 2.306 & $\begin{array}{l}\text { Signifi } \\
\text { cant }\end{array}$ \\
\cline { 2 - 4 } & $\begin{array}{l}\text { Post } \\
\text { test }\end{array}$ & 12 & & & \\
\hline
\end{tabular}

The table above shows that the average score of the students on pre test was calculated as 7.89 and the average score and the average score of the students on post test was calculated as 12 . The accounted $\mathrm{t}$-value was $\mathrm{t}=3.83$ and standard of significant 0.05 . Since t observed was bigger than $\mathrm{t}$ table (tobserved $>\mathrm{t}$ table), null hypothesis (Ho) was rejected and alternative hypothesis (Hi) was accepted. So, based on these results, it was concluded that there was statistically diffrence between the pre-test in 0.05 levels. It means that the teaching argemnetative writing planned and implemented based on semantic mapping theory gave significant effect on students' argumentaive writing ability.

Based on the statistical analysis of the hypotheses testing, it was found that teaching writing prepared based on semantic mapping teory give significant effect on students' argumentative writing ability. There are some explanation for the result found in this research.First, it was found that there is a significant diffrence between pre-test and posttest score of the students in term of the usage of teaching writing prepared based on semantic mapping theory toward their argumentative writing ability. The students who were taught based on semantic mapping theory become motivated to write and improve their writing achievement. In other word, teaching activities prepared based on semantic mapping theories have changed students' perception about writing. This finding is consistent with the theory, stated in reviwe of the related literature, proposed by
(Branch \&Campus, 2017) who say that stimulating students to express themselves in words, and encourage them to think critically and broadly. To complete the learning circle, if students are able to be more creative, they can in turn make the map talk even more.

Second, based on the results of observations done during the teaching-learning processes, the researcher's performance in implementing the Semantic Mapping for teaching argumentative writing was good. It could be said because during the learning prosess students gave positive response and highly enthusiastic to participate in learning writing through the Semantic Mapping technique. Therefore their motivation increased. Through the semantic mapping activity, students can internalize the language and structure of the argumentaive text. Therefore, they can improve their argumenatative writing achievement. Moreover, Jhonson (2008:132) states that argument mapping is open ended activities in which students all levels can experience some level of success. He also adds that students can design and create their own story map so that it provides a good sense of how students comprehend story events.

In conclusion, the students can show their improvement when the writing activity by using semantic mapping. The students' progress of content was influenced by implementing the semantic mapping technique. They design their ideas into sub topics through semantic mapping technique, so they could develop their ideas and vocabularies based on the topic of semantic mapping in writing. Using semantic mapping, the students can use more variety vocabularies, so their writing is not monotone. The students were accustomed to think critically on delivering 
their idea of the topic represented in descriptive text since they had to contribute by giving the ideas. Meanwhile, the students' improvement on organization was obtained through parts of the argument that had been discussed during the implementation. During the implementation the students showed great enthusiastic and paid attention. It is proven improving students' ability in writing which could be in from the achievement test after the implementation of the semantic mapping technique. Therefore, based on the improvement of students' writing score, the semantic mapping technique was done successfully to help students to improve their writing skill.

\section{CONCLUSION}

Based on the data and the result of analysis that have been described, it can be concluded that there is a significant diffrence between pre-test and post-test score of the students in term of the usage of teaching argumentative writing prepared based on semantic mapping theory toward their writing ability. It meant that providing semantic mapping is one way of supporting students to be more critical and successful in the classroom.Thus, it can be concluded that teaching argumentative writing prepared based on semantic mapping theory have significant effect on student' writing ability. It has been proved statistically by the calculation of t-test for related samples and Wilcoxon t-test. The result of the calculation of t-test for related samples indicated that tobserved could exceed the $t$ table . Reffering to this result, the research hypothesis is accepted. Besides, the result of the calculation of Wilcoxon t-test indicated that $\mathrm{Z}$ score is smaller than critical value. Refering to this result, the reserach hypothesis is accepted.

\section{REFERENCES}

Bellegarda, J. R. (2007). Latent Semantic Mapping Principles \& Application. Los Angles.

D, I. M. R. A. P. (2014). Employing Concept Mapping as a Pre-writing Strategy to Help EFL Learners Better Generate Argumentative Compositions Employing Concept Mapping as a Pre-writing Strategy to Help EFL, 8(2).

Dwyer, C. P., Hogan, M. J., \& Stewart, I. (2015). The effects of argument mapping-infused critical thinking instruction on reflective judgement performance, 16, 11-26.

George Hilloks. (2011). Teacher Argument Mapping, Grade G-12 Support Claims with Relevant Evidence and Clear Reasoning. Los Angles: Heineman Educational Books.

Hasani, A. (2016). Enhancing argumentative writing skill through contextual teaching and learning, 11(16), 1573-1578. https://doi.org/10.5897/ERR2016.2806

Joan E Heimlich. (1986). Semantic Mapping: Classroom Application (Reads AIDS series).Los Angles.

K.J Peters. (2018). The Argument Hand Book. Canada: Broadview Press Ltd.

Katagall, R., Dadde, R., Goudar, R. H., \& Rao, S. (2015). Concept Mapping in Education and Semantic Knowledge Representation: an Illustrative Survey. Procedia - Procedia Computer Science, 48(Iccc),638-643. https://doi.org/10.1016/j.procs.2015.04. 146

Leydesdorff, L., \& Welbers, K. (2011). The semantic mapping of words and co-words in contexts. Journal of Informetrics, $5(3), 469-475$.

https://doi.org/10.1016/j.joi.2011.01.08

Liu, F., \& Stapleton, P. (2014) Counterargumentation and the cultivation of critical thinking in argumentative writing : Investigating washback from a high-stakes test. System, 45, 117-128. 
https://doi.org/10.1016/j.system.2014.05. 005

Ma, U. A., \& Ma, M. Y. (2015). The Effect of Semantic Mapping Instruction on Iranian Undergraduate Students 'Writing and Recall, 9(1), 21-29.

Nurcihan, Y. (2013). Using semantic mapping technique in vocabulary teaching at preintermediate level, 70, 1531-1544. https://doi.org/10.1016/j.sbspro.2013.01.2 21

Preiss, D. D., Castillo, J. C., Flotts, P., \& Martín, E. S. (2013). Assessment of argumentative writing and critical thinking in higher education: Educational correlates and gender differences. Learning and Individual Differences. https://doi.org/10.1016/j.lindif.2013.06.00 4

Scott, P., \& Worden, R. (2012). Semantic mapping to simplify deployment of HL7 v3 Clinical Document Architecture. Journal of Biomedical Informatics, 45(4), 697-702.

https://doi.org/10.1016/j.jbi.2012.02.006

Zahedi, Y., \& Abdi, M. (2012). International Conference on Education and Educational Psychology ( ICEEPSY 2012 ) The effect of semantic mapping strategy on EFL learners' vocabulary learning. Procedia Social and Behavioral Sciences, 69(Iceepsy),2273-2280.

https://doi.org/10.1016/j.sbspro.2012.12.1 98 